\title{
Interleukin 1 (IL-1) Gene Expression, Synthesis, and Effect of Specific IL-1 Receptor Blockade in Rabbit Immune Complex Colitis
}

\author{
Fabio Cominelli, Cynthia C. Nast, ${ }^{*}$ Burton D. Clark, ${ }^{5}$ Ralf Schindler, ${ }^{5}$ Rafael Llerena, Viktor E. Eysselein, \\ Robert C. Thompson, ${ }^{*}$ and Charles A. Dinarello \\ Departments of Medicine and *Pathology and Inflammatory Bowel Disease Center, Harbor-University of California at Los Angeles \\ Medical Center, Torrance, California 90502; ${ }^{\ddagger}$ Synergen Inc., Boulder, Colorado 80301; $\$$ Department of Medicine and \\ New England Medical Center, Tufts University, Boston, Massachusetts 02111
}

\begin{abstract}
Interleukin 1 (IL-1) may be a key mediator of inflammation and tissue damage in inflammatory bowel disease (IBD). In rabbits with immune complex-induced colitis, IL-1 $\alpha$ and $\beta$ mRNA levels were detectable at $4 \mathrm{~h}$, peaked at 12 but were absent at $96 \mathrm{~h}$ after the induction of colitis. Colonic IL-1 tissue levels were measured by specific radioimmunoassays. IL-1 $\alpha$ was significantly elevated at $4 \mathrm{~h}(9.4 \pm 1.5 \mathrm{ng} / \mathrm{g}$ colon $)$, progressively increased at $48 \mathrm{~h}(31 \pm 5.8 \mathrm{ng} / \mathrm{g})$ and then decreased by $96 \mathrm{~h}(11.5 \pm 3.4 \mathrm{ng} / \mathrm{g})$. IL-1 $\beta$ levels were $2.0 \pm 0.5 \mathrm{ng} / \mathrm{g}$ colon at $4 \mathrm{~h}, 5.0 \pm 1.6 \mathrm{ng} / \mathrm{g}$ at $48 \mathrm{~h}$ and undetectable by $96 \mathrm{~h}$. By comparison, colonic levels of $\mathrm{PGE}_{2}$ and $\mathrm{LTB}_{4}$ were unchanged during the first $12 \mathrm{~h}$ and did not become elevated until $24 \mathrm{~h}$. IL-1 $\alpha$ levels were highly correlated with inflammation $(r=0.885, P$ $<0.0001)$, edema $(r=0.789, P<0.0001)$ and necrosis $(r$ $=0.752, P<0.0005)$. Treatment with a specific IL-1 receptor antagonist (IL-1ra) before and during the first $33 \mathrm{~h}$ after the administration of immune complexes markedly reduced inflammatory cell infiltration index (from $3.2 \pm 0.4$ to $1.4 \pm 0.3, P$ $<0.02$ ), edema (from $2.2 \pm 0.4$ to $0.6 \pm 0.3, P<0.01$ ) and necrosis (from $43 \pm 10 \%$ to $6.6 \pm 3.2 \%, P<0.03$ ) compared to vehicle-matched colitis animals. These studies demonstrate that (a) IL-1 gene expression and synthesis occur early in the course of immune complex-induced colitis; $(b)$ are significantly elevated for $12 \mathrm{~h}$ before the appearance of $\mathrm{PGE}_{2}$ and $\mathrm{LTB}_{4} ;(c)$ tissue levels of IL-1 correlate with the degree of tissue inflammation and; $(d)$ specific blockade of $I L-1$ receptors reduces the inflammatory responses associated with experimental colitis. (J. Clin. Invest. 1990. 86:972-980.) Key words: interleukin 1 • interleukin 1 receptor antagonist $\bullet$ colitis
\end{abstract}

\section{Introduction}

Interleukin-1 (IL-1) is a polypeptide cytokine produced during inflammation and injury, that possesses a wide spectrum of

Presented in part at the Second International Workshop on Cytokines, Hilton Head Island, SC, December 1989, and at the Western Section of the American Federation of Clinical Research, Carmel, CA, February 1990. Address reprint requests to Dr. Cominelli, Division of Gastroenterology, C-1 Trailer, Harbor-UCLA Medical Center, 1124 W. Carson Street, Torrance, CA 90502.

Received for publication 26 October 1989 and in revised form 17 May 1990.

J. Clin. Invest.

(c) The American Society for Clinical Investigation, Inc.

0021-9738/90/09/0972/09 \$2.00

Volume 86, September 1990, 972-980 immunologic and nonimmunologic activities (1). Two distinct gene products of IL- 1 have been identified: IL- $1 \beta$, which is secreted by cells, and IL- $1 \alpha$, which is primarily a cell-associated protein (2-4). Both forms share the same spectrum of biological activities and recognize the same cell surface receptors (reviewed in 1). Interest has focused on the role of IL-1 as an inflammatory mediator in chronic and acute diseases $(5,6)$. Elevated IL-1 levels have been reported in synovial fluid and plasma from patients with various arthritides (7-9). In addition, patients with acute meningitis, septic shock, or burn injuries often show increased circulating levels of IL-1 $(10,11)$. Increased IL-1 production by blood mononuclear cells has been described in several pathologic conditions including rheumatoid arthritis and Crohn's disease (12-14).

Several of the biological properties of IL-1 are relevant to inflammatory bowel disease. When injected in rabbits, IL-1 induces fever, neutrophilia, decreased plasma iron, zinc and albumin levels, and synthesis of acute-phase proteins (1). IL-1 attracts leukocytes into inflamed tissues (15) and stimulates prostaglandin synthesis by its ability to induce cyclooxygenase gene expression (16). Thus, systemic and local IL-1 production may initiate or contribute to the inflammatory response in colitis and could play a role in the pathogenesis of this disease. Our recent studies are consistent with this hypothesis, as IL-1 perfused in or incubated with rabbit colons induced prostaglandin and thromboxane production (17).

We have previously used the rabbit model of formalin-immune complex colitis to investigate the role of arachidonic acid-derived inflammatory mediators and to evaluate therapeutic strategies in colitis (18-20). The availability of specific cDNA probes and radioimmunoassays for rabbit IL- $1 \alpha$ and IL-1 $\beta(21,22)$, as well as a specific IL-1 receptor antagonist (IL-1 ra) $(23,24)$ offers an opportunity to study the role of IL-1 in this model. Therefore, the aims of the present study were to examine the time course of IL-1 gene expression and synthesis in the colon of rabbits after induction of formalin-immune complex colitis and to determine whether selective blockade of IL-1 receptors would reduce the subsequent colonic inflammatory response. Here we report that IL-1 is produced just before the sequence of histological events and eicosanoid synthesis characteristic of this colitis model and that specific inhibition of IL-1 activity significantly reduces inflammation and necrosis, suggesting that IL-1 plays a major role in the pathogenesis of colonic inflammation.

\section{Methods}

Rabbit colitis model. Inflammation was induced in the distal colon of male New Zealand rabbits $(2.2-2.5 \mathrm{~kg})$ using a modification of the immune complex method of colitis $(25,26) .4 \mathrm{ml}$ of $0.45 \%$ (vol/vol) unbuffered formaldehyde (Electron Microscopy Sciences, Fort Wash- 
ington, PA) was administered by a catheter inserted $10 \mathrm{~cm}$ into the distal colon of anesthetized rabbits (xylazine and ketamine). $2 \mathrm{~h}$ later, animals received $0.85 \mathrm{ml}$ of immune complexes in antigen excess through an ear vein. The complexes were prepared by incubating human serum albumin $(500 \mu \mathrm{g} / \mathrm{ml})$ with rabbit antihuman antisera (ICN Immunobiologicals, Costa Mesa, CA), decanting the supernatant, and redissolving the precipitated immune complexes with an albumin solution $(6 \mathrm{mg} / \mathrm{ml})$ as described previously (18).

Time course study. Animals were killed with $40 \mathrm{mg} / \mathrm{kg}$ of nembutal (Abbot Laboratories, North Chicago, IL) 0, 4, 12, 24, 48, and $96 \mathrm{~h}$ after induction of colitis and the distal colon removed. Longitudinal sections from the last $10 \mathrm{~cm}$ of the distal colon were obtained and processed for histologic assessment of inflammation, IL-1 mRNA analysis and IL-1 protein measurements. Noninvolved small intestine was also removed for study. Rectal dialysis was performed for $2 \mathrm{~h}$ immediately before each time point for measurement of $\mathrm{PGE}_{2}$ and leukotriene $\mathrm{B}_{4}$ $\left(\mathrm{LTB}_{4}\right)^{1}$ as previously described (18).

Treatment with recombinant human IL-1 ra. Recombinant interleukin-1 receptor antagonist, rIL-1 ra, was prepared from lysates of Escherichia coli transformed with a plasmid containing a modified IL-1 ra cDNA under control of the tac promoter (23). Expression of IL-1 ra was induced by the addition of isopropylthio- $\beta$-D-galactoside for several hours, and the cells were collected by centrifugation and lysed in a pressure cell. The recombinant protein was purified by successive cation and anion exchange chromatography and was $>95 \%$ pure by SDS-PAGE and by reverse-phase HPLC. It contained $<0.2$ endotoxin $\mathrm{U} / \mathrm{mg}$ of protein. The homogenous protein $(18 \mathrm{kD})$ was suspended in $0.5 \mathrm{ml} \mathrm{PBS} \mathrm{(0.1} \mathrm{M} \mathrm{phosphate,} 0.15 \mathrm{M} \mathrm{NaCl}, \mathrm{pH} 7.4)$. The rIL-1 ra inhibits IL-1 activity in vitro by binding to cell surface receptors and competitively inhibiting IL-1 binding. This effect has been demonstrated in the murine thymoma cell line EL4-6.1 (24). The ability of rIL-1 ra to block the biological actions of IL- 1 has been demonstrated in human foreskin fibroblasts (23), in human rheumatoid synovial fibroblasts and chondrocytes (27), and in human endothelial cells (28). Tests with the natural IL-1 ra have shown that it does not block the action of TNF on dermal fibroblasts (29). When administered intravenously at 100 times the dose of IL-1 it blocks the drop in blood pressure and the drop in circulating white blood cells in the rabbit (30). Animals were treated intravenously with IL- $1 \mathrm{ra}(5 \mathrm{mg} / \mathrm{kg}$; $n=8)$ or the vehicle $(n=10)$ at six time points: $2 \mathrm{~h}$ before and $1,9,17$, 25 , and $33 \mathrm{~h}$ after the administration of the immunocomplexes. The rabbits were killed $48 \mathrm{~h}$ after the induction of colitis and colon tissue analyzed for inflammation.

Histologic quantitation of inflammation. Histologic evaluation was performed on a minimum of two longitudinal sections from each colon as previously described (18). All colon samples were examined in a blind fashion by a single pathologist (C. C. Nast). The mucosa and submucosa were separately evaluated for infiltration of acute inflammatory cells (neutrophils and eosinophils). A semiquantitative score of leukocytes (L) per high power field (HPF) was determined for each area examined using the following quantitations: $0=0$ or $1 ; 0.5=2-9$; $1=10-20 ; 1.5=21-30 ; 2=31-40 ; 2.5=41-50 ; 3=51-65 ; 3.5$ $=66-80 ; 4=\geq 81 \mathrm{~L} / \mathrm{HPF}$. At a minimum, eight HPFs of mucosa and submucosa from each specimen were separately evaluated in each section. The inflammatory index was calculated by adding the averaged score for the mucosal and submucosal evaluations. Edema was semiquantitatively assessed on a scale of 0 to 4 . Necrosis was expressed as the percentage of mucosa involved.

$I L-1 \alpha$ and $I L-1 \beta$ radioimmunoassays. IL- $1 \alpha$ and IL- $1 \beta$ were measured using specific, non-cross-reacting radioimmunoassays (22). These assays were also validated for IL-1 levels after tissue extraction (22). Longitudinal sections were immediately frozen in liquid nitrogen until assay. At that time, $1 \mathrm{~g}$ frozen tissue was thawed and lysed in 10

1. Abbreviations used in this paper: $\mathrm{LTB}_{4}$, leukotriene $\mathrm{B}_{4} ; \mathrm{TNF}$, tumor necrosis factor. ml PBS containing a cocktail of protease inhibitors (antipain, aprotinin, leupeptin, pepstatin A, all at $1 \mu \mathrm{g} / \mathrm{ml}$ and PMSF, $1 \mathrm{mM}$ ) (Sigma Chemical Co., St. Louis, MO). Tissue was homogenized with an electric homogenizer for $30 \mathrm{~s}$. The homogenate was then centrifuged for 60 $\min$ at $100,000 \mathrm{~g}$ at $15^{\circ} \mathrm{C}$. The supernatant was decanted and assayed directly for IL- $\alpha$ and IL- $1 \beta$ levels. In brief, $100 \mu$ l of goat anti-rabbit IL-1, appropriately diluted in assay buffer $(0.25 \%$ BSA, $0.05 \%$ azide, $0.01 \mathrm{M}$ PBS, pH 7.4; anti-IL- $\alpha$ at $1: 200,000$ and anti-IL- $1 \beta$ at $1: 6,400$ ) were added to $100 \mu \mathrm{l}$ of colon tissue sample, followed by 300 $\mu \mathrm{l}$ of assay buffer. The tubes were vortexed and incubated overnight at room temperature. ${ }^{125} \mathrm{I}-\mathrm{IL}-1 \alpha$ or ${ }^{125} \mathrm{I}-\mathrm{IL}-1 \beta(10-12,000 \mathrm{cpm})$ was then added, the tubes vortexed again and incubated for an additional $24 \mathrm{~h}$ at room temperature. $500 \mu \mathrm{l}$ of $6 \%$ polyethylene glycol $(8,000 \mathrm{~mol} \mathrm{wt})$, and $2 \%$ donkey anti-goat IgG serum (Cambridge Medical Diagnostic, Billerica, MA) diluted in assay buffer were added to precipitate the bound immune complexes from the free ${ }^{125} \mathrm{I}-\mathrm{IL}-1$. The samples were vortexed, incubated for $1 \mathrm{~h}$, centrifuged at $2,000 \mathrm{~g}$ for $20 \mathrm{~min}$ at $4^{\circ} \mathrm{C}$, and the supernatants were decanted; the precipitates were counted in a gamma-counter. All samples were tested in duplicate; standard curves were prepared with rabbit recombinant IL- $1 \alpha$ and IL- $1 \beta$. The RIAs have a detection limit of $40 \mathrm{pg} / \mathrm{ml}$ and $60 \mathrm{pg} / \mathrm{ml}$ for IL- $1 \alpha$ and IL- $1 \beta$, respectively, at the $95 \%$ confidence level (22).

mRNA analysis. Longitudinal sections of distal colon were immediately frozen in liquid nitrogen after dissection. Approximately $0.25 \mathrm{~g}$ frozen tissue was lysed in $10 \mathrm{ml}$ of guanidium isothiocyanate solution using an electric homogenizer for $30 \mathrm{~s}$. Total RNA was extracted by centrifugation through $5.7 \mathrm{M} \mathrm{CsCl}$ (prepared by dissolving $\mathrm{CsCl}$ in 0.1 M EDTA). The RNA pellet was resuspended in $0.25 \mathrm{ml}$ resuspension buffer ( 5 mM EDTA, $0.5 \%$ sarkosyl, and $5 \% \beta$-mercaptoethanol) and the concentration determined by ultraviolet at $260 / 280 \mathrm{~nm}$ ratio spectrophotometry. For Northern blot analysis $30 \mu \mathrm{g}$ of total RNA was loaded per lane on a $1.2 \%$ agarose gel containing $1.6 \%$ formaldehyde. After electrophoresis, the gel was soaked in water for $30 \mathrm{~min}$ to remove the formaldehyde and the RNA was transferred to nylon membranes (Hybond-N; Amersham Corp., Arlington Heights, IL) by capillary action and fixed by ultraviolet radiation as described by the manufacturer. The blots were prehybridized for 3-12 $\mathrm{h}$ with prehybridization buffer followed by hybridization with the cDNA probes $(31,32)$. The rabbit IL- $1 \alpha$ DNA probe used in these experiments is a $830 \mathrm{bp}$ Eco RI-Bgl II fragment from the IL- $1 \alpha$ cDNA in pUC19 (21). The rabbit IL- $1 \beta$ probe is a 830 bp Eco RI-Eco RI fragment of the full length cDNA (21). Probes were labeled with $\left[{ }^{32}\right.$ P]dCTP (DuPont NEN, Wilmington, DE) by use of a random primer DNA labeling kit (Boehringer Mannheim Biochemicals, Indianapolis, IN) to specific activity of $10^{8}-10^{9} \mathrm{cpm} / \mu \mathrm{g}$ ).

Eicosanoid radioimmunoassay. $\mathrm{PGE}_{2}$ and $\mathrm{LTB}_{4}$ were measured in rectal dialysates by validated radioimmunoassays after lipid extraction and purification by Sephadex LH-20 and high pressure chromatography $(33,34)$.

Data analysis. Results are expressed as mean \pm SEM. Statistical analysis was performed using a statistical software (BMDP Inc., Los Angeles, CA). Statistical significance between groups of parametric data was evaluated using Student's $t$ test for unpaired data. Comparison between group of nonparametric data were made with the MannWhitney two-sample test. Correlations were made using the Pearson's $r$ test. The differences were considered significant when the $P$ value was $<0.05$.

\section{Results}

Development of colonic inflammation. The time course of the inflammatory response in the rabbit model is shown in Table I. After the administration of formalin, followed by immune complexes, the distal colon develops acute inflammation. This is characterized by infiltration of neutrophils primarily into the mucosa and submucosa, mucus depletion, crypt abscesses, edema, and scattered areas of mucosal necrosis. Inflammatory 
Table I. Time Course of the Inflammatory Response in Rabbit Formalin-immune Complex Colitis

\begin{tabular}{cccc}
\hline Time & Inflammatory index & Edema & \% Necrosis \\
\hline$h$ & & & \\
0 & $0.3 \pm 0.1$ & $0 \pm 0$ & $0 \pm 0$ \\
4 & $1.6 \pm 0.2^{*}$ & $1.6 \pm 0.5^{*}$ & $0 \pm 0$ \\
12 & $2.8 \pm 0.3^{*}$ & $1.9 \pm 0.4^{*}$ & $12 \pm 6^{*}$ \\
24 & $3.5 \pm 0.5^{*}$ & $2.7 \pm 0.5^{*}$ & $45 \pm 22^{*}$ \\
48 & $4.5 \pm 0.7^{*}$ & $3.6 \pm 0.3^{*}$ & $89 \pm 3^{*}$ \\
96 & $1.3 \pm 0.7^{* \pm}$ & $1.2 \pm 0.5^{* \ddagger}$ & $11 \pm 10^{* \ddagger}$
\end{tabular}

Colitis was induced at time 0 ; colon tissue was obtained at each time point indicated above and processed for light microscopy. Inflammatory cell infiltration index, edema and percent of mucosal necrosis were measured and scored (see Methods). The data are the mean $\pm \mathrm{SEM}$ of five rabbits at each time point.

${ }^{*} P<0.001$ vs. $0 \mathrm{~h},{ }^{\ddagger} P<0.01$ vs. $48 \mathrm{~h}$.

cell infiltration index, edema, and percentage of mucosal necrosis, progressively increased from $0.3 \pm 0.1(0 \mathrm{~h})$ to $4.5 \pm 0.7$ (48 h) $(P<0.001)$, from $0.3 \pm 0.1$ to $3.6 \pm 0.3(P<0.001)$ and from $0 \%$ to $89 \%(P<0.001)$, respectively. A subsequent decrease in these parameters was observed $96 \mathrm{~h}$ after the induction of colitis $(P<0.01$ vs. $48 \mathrm{~h})$.

Synthesis of $I L-1 \alpha$ and $I L-1 \beta$. IL- $1 \alpha$ and IL- $1 \beta$ levels were undetectable $(<40 \mathrm{pg} / 100 \mathrm{mg}$ of tissue for IL- $1 \alpha$ and $<60$ $\mathrm{pg} / 100 \mathrm{mg}$ of tissue for IL- $1 \beta)$ in colon specimens obtained from healthy rabbits before the induction of colitis $(0 \mathrm{~h})$. A significant increase in colon tissue levels of IL- $1 \alpha$ and IL- $1 \beta$ was observed at $4 \mathrm{~h}(P<0.01)$ with a maximum at $48 \mathrm{~h}$ after the induction of colitis. In contrast, IL- $1 \alpha$ and IL- $1 \beta$ concentrations were markedly diminished at $96 \mathrm{~h}$ in parallel to the decrease in inflammation and tissue damage (Fig. 1). IL- $1 \alpha$ tissue concentrations were approximately five times greater than IL- $1 \beta$ levels. Inflammatory index, edema, and percentage of mucosal necrosis correlated with IL- $1 \alpha$ and IL- $1 \beta$ levels. The correlations were $r=0.885(P<0.0001), r=0.789(P$ $<0.0001)$ and $r=0.752(P<0.0005)$ for IL- $1 \alpha$ (Fig. $2 A)$ and $r$ $=0.706(P<0.001), r=0.792(P<0.0001)$ and $r=0.604(P$ $<0.005$ ) for IL-1 $\beta$ (Fig. $2 B$ ), respectively. Both IL- $\alpha$ and IL- $1 \beta$ were absent in noninflamed small intestinal tissues obtained from the same animals.

$I L-1 \alpha$ and $I L-1 \beta$ gene expression. The transcriptional activation of rabbit IL- $1 \alpha$ and IL- $1 \beta$ mRNA production in the colon during the induction of colitis was examined by Northern blot analysis. The membrane was first hybridized with the probe for rabbit IL- $1 \beta$, stripped, and rehybridized with the rabbit IL- $1 \alpha$ probe. In three separate experiments, we did not observe evidence of IL- $1 \alpha$ or IL- $1 \beta$ mRNA before the onset of colitis $(0 \mathrm{~h})$. IL-1 $\beta$ mRNA was clearly observed as early as $4 \mathrm{~h}$ after the injection of immune-complexes, whereas IL- $1 \alpha$ mRNA in the same tissue sample was weakly visible. Peak mRNA was present for both IL- $1 \alpha$ and IL- $1 \beta$ at $12 \mathrm{~h}$. At $96 \mathrm{~h}$ there was no evidence of continued presence of IL-1 mRNA. Fig. 3 illustrates the Northern blot of one of the three experiments. IL- $1 \alpha$ and IL- $1 \beta$ mRNA was not observed in noninflamed control samples obtained from the small intestine of the same animals.

Production of colonic $P G E_{2}$ and $L_{T} B_{4}$. The time course of $\mathrm{PGE}_{2}$ and $\mathrm{LTB}_{4}$ production during the induction of colitis is shown in Fig. 4. No changes in these eicosanoids were observed at 4 and $12 \mathrm{~h}$. A significant increase in colonic $\mathrm{PGE}_{2}$ and $\mathrm{LTB}_{4}$ levels was observed only at 48 and $24 \mathrm{~h}$, respectively. At $96 \mathrm{~h}$, colonic $\mathrm{PGE}_{2}$ and $\mathrm{LTB}_{4}$ production diminished to levels similar to those observed in control rabbits $(0 \mathrm{~h})$.

Effects of treatment with IL-1 ra. Treatment of rabbits with human recombinant IL-1 ra significantly reduced inflammatory index from $3.2 \pm 0.4$ to $1.4 \pm 0.3(P<0.02)$, edema from $2.2 \pm 0.4$ to $0.6 \pm 0.3(P<0.01)$ and necrosis from $43 \pm 10 \%$ to $6.6 \pm 3.2 \%(P<0.03)$ compared to vehicle-treated colitis animals (Fig. 5). Representative macroscopic appearance and histologic sections of distal colons obtained from the two experimental groups are shown in Fig. 6.

\section{Discussion}

There is increasing evidence that IL-1 is one of the key mediators of the inflammatory response after microbial invasion, immunological reactions, and tissue injury. In this report we show that IL- $1 \alpha$ and IL- $1 \beta$ synthesis occurs early in the rabbit model of formalin-immune complex colitis. The rapid tran-
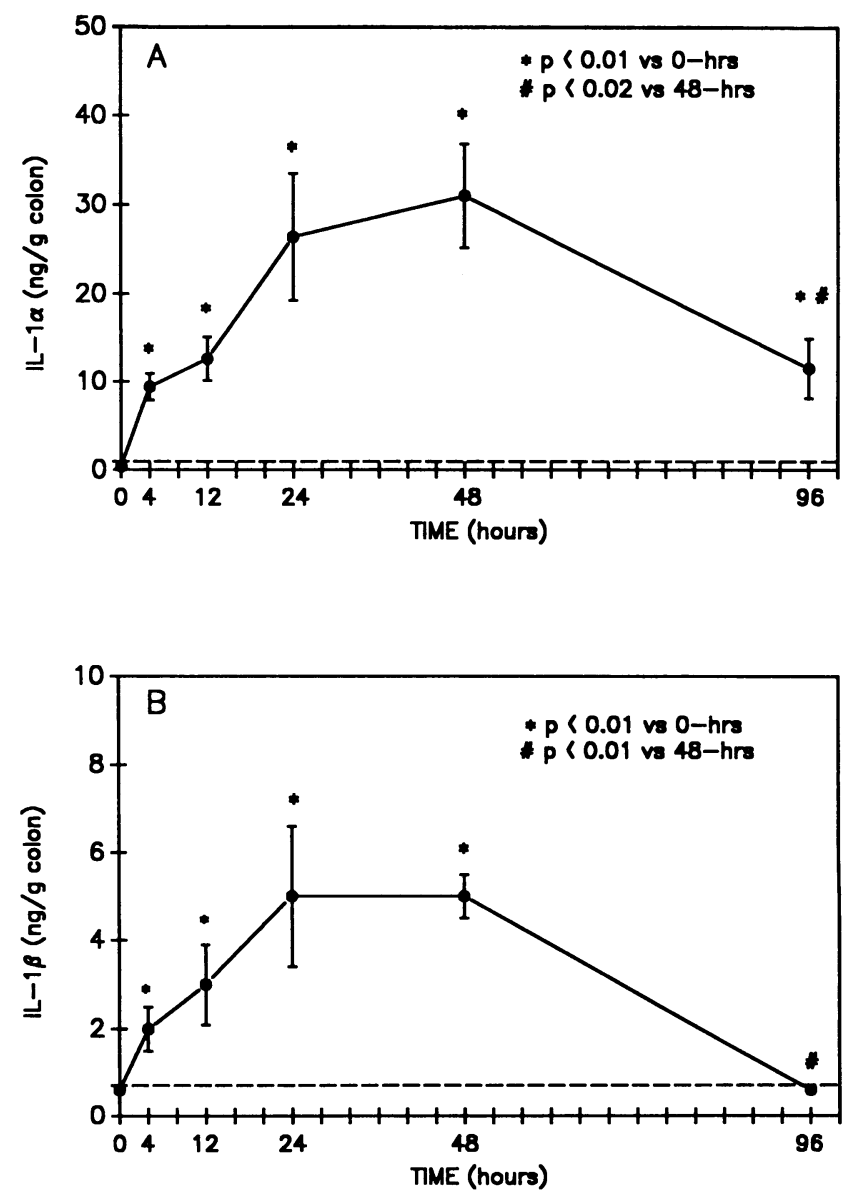

Figure 1. Time course of IL-1 production in colonic tissue after administration of intravenous immunocomplexes. IL- $1 \alpha(A)$ and IL-1 $\beta$ $(B)$ were measured by specific radioimmunoassays after tissue extraction (see text for details). Colonic tissue IL-1 levels were below the detection limit (dashed line) at time 0 and increased up to $48 \mathrm{~h}$ ( $P$ $<0.01$ ). A significant decrease in IL- $1 \alpha$ and IL- $1 \beta$ production was observed at $96 \mathrm{~h}$ after colitis induction $(P<0.01)$. Each point represents the mean \pm SEM of five rabbits. 

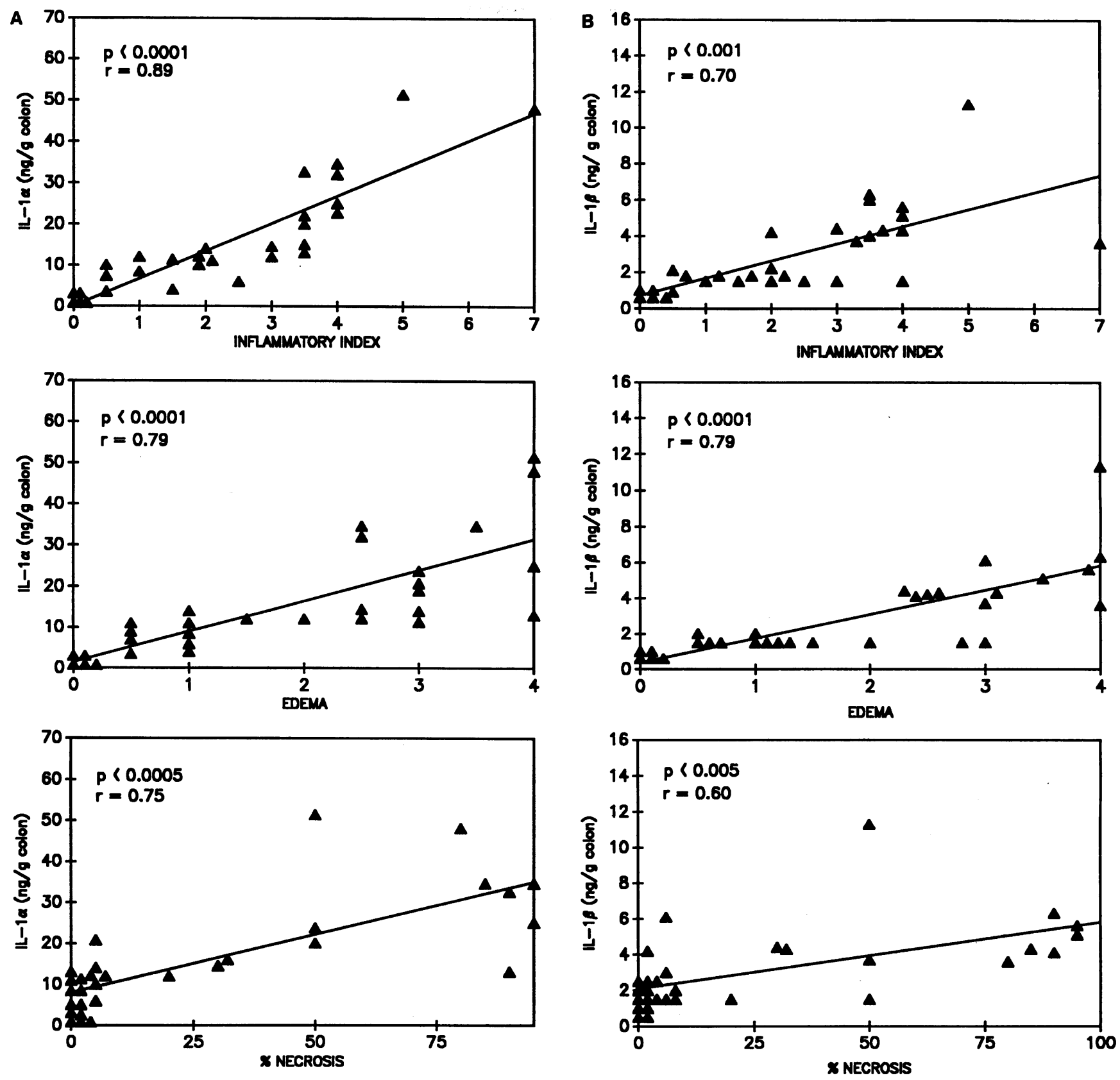

Figure 2. Relationship of colonic tissue IL-1 levels to inflammation and tissue injury. Inflammatory index, edema and mucosal necrosis were microscopically assessed on coded samples. Correlations coefficients were determined from all data points of IL-1 and histologic scores. $(A)$ Correlation with IL-1 $\alpha$. (B) Correlation with IL-1 $\beta$.

scriptional activation and appearance of IL-1 in the colonic tissue after the initiation of colitis were clearly demonstrated in these studies. Tissue levels of IL-1 rapidly increased at $4 \mathrm{~h}$, reached maximal or near maximal levels at 24-48 $\mathrm{h}$ and then decreased to control values by $96 \mathrm{~h}$ after the induction of colitis. In parallel, IL- $1 \alpha$ and IL- $1 \beta$ mRNA levels, undetectable before the induction of colitis, were found at $4 \mathrm{~h}$, peaked at $12 \mathrm{~h}$, but were undetectable by $96 \mathrm{~h}$. Moreover, the relationship of IL-1 synthesis to the increase in inflammation and tissue damage is of particular importance. There were highly significant correlations between IL- $1 \alpha$ tissue levels and the inflammatory cell infiltration index, edema and necrosis $(r$ $=0.89,0.79$, and 0.75 , respectively). Rachmilevitz et al. have recently shown increased colonic IL-1 production in a rat model of colonic inflammation (35). However, in the latter study, IL-1 activity was measured by bioassays which are known to detect IL-2, IL-4, IL-6, and IL-7. In combination these results suggest that IL- 1 plays an important role in initiating colonic inflammation. The marked reduction in inflammatory cell infiltration, edema and necrosis seen after the administration of the IL-1 ra provides additional strong support for this hypothesis.

Several of the biological properties of IL-1 place this cytokine in a strategic position during the cascade of inflammatory responses in this model. IL-1 triggers gene expression for several inflammatory cytokines (1). Of these, the ability of IL-1 to 


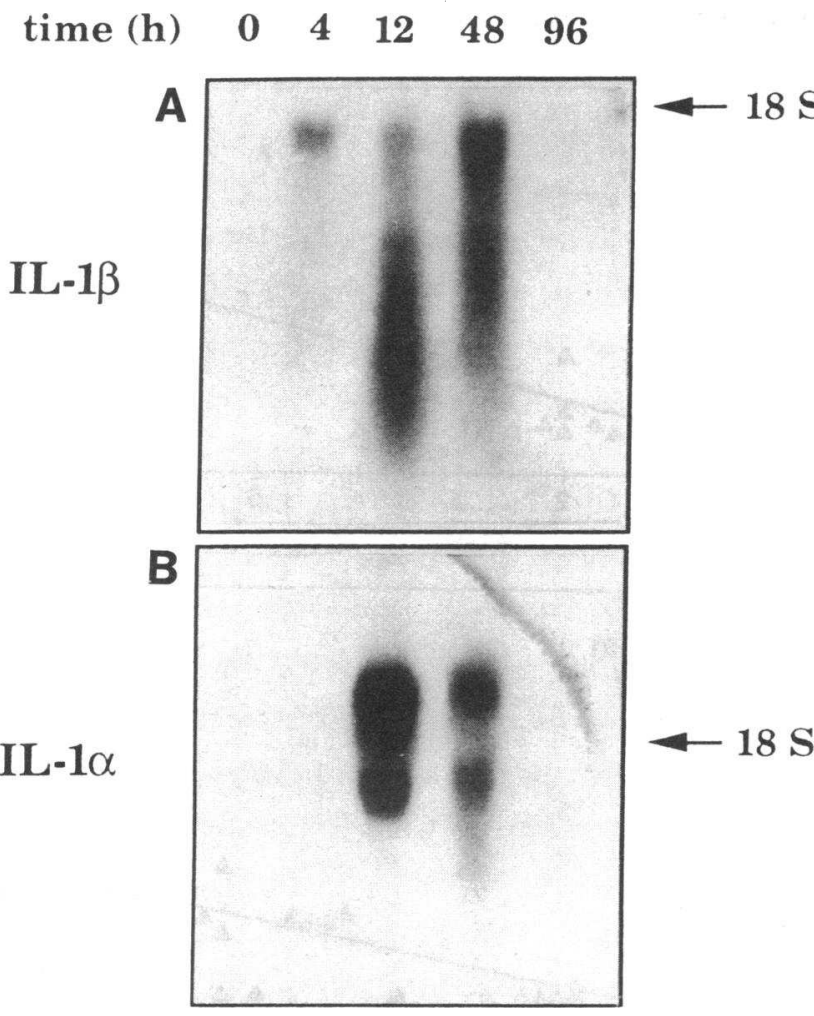

Figure 3. Northern blot analysis of colonic extract using a cDNA to rabbit IL-1. Colonic tissue was obtained at the times indicated after induction of colitis for isolation of total RNA. $(A)$ Hybridization with an 830-bp IL-1 $\beta$ probe. (B) Hybridization with a 830 -bp IL-1 $\alpha$ to the same Northern blot after stripping the probe.

induce neutrophil-activating protein-1 (IL-8) (36-38) and other monocyte-derived chemotactic factors (39) is particularly important since these factors may account for the emigration of neutrophils and monocytes into the injured colon. In addition to IL-8, IL-1 stimulates gene expression of itself, tumor necrosis factor, colony stimulating proteins and IL-2 through IL-6 (1). Therefore, IL-1 may be a primary initiator of inflammation as well as be involved in the prolongation of the lesions associated with this model. The ability of the IL-1 ra to reduce significantly colonic inflammation speaks for the importance of IL-1 in both phases of the colitis, but does not rule out the participation of other mediators.

Colon IL- $1 \alpha$ concentrations were five times greater than IL- $1 \beta$ levels. In contrast, IL- $1 \beta$ mRNA levels were greater at 4 $h$ and similar to those of IL- $1 \alpha$ at 12 and $48 \mathrm{~h}$. These results are in accord with other studies in human mononuclear cells where IL- $1 \beta$ mRNA has been found to be predominant (40), whereas cell-associated IL- $1 \alpha$ is produced in greater amounts in response to endotoxin stimulation $(4,41,42)$. These observations suggest differences in the regulation of IL- $1 \alpha$ and IL- $1 \beta$ at the transcriptional and translational levels. We have recently shown that IL- $1 \alpha$ is more potent and more effective than IL- $1 \beta$ in inducing eicosanoid production in rabbit colon (18). Taken together these data suggest that IL-1 $\alpha$ may be the predominant form of IL-1 produced by the rabbit colon. Preferential production of IL- $1 \alpha$ has been noted in other tissues and cell types; for example human keratinocytes appear to produce predominantly IL- $1 \alpha(43)$.
Inflammation and necrosis were decreased by $96 \mathrm{~h}$ after the induction of colitis consistent with the decreases in IL-1 mRNA levels and IL-1 proteins. We have recently shown that pretreatment of rabbits with a low-dose of IL- $1 \beta 24 \mathrm{~h}$ before the induction of colitis protects against the subsequent development of inflammation through a mechanism that requires enhanced prostaglandin synthesis (44). The increased synthesis of $\mathrm{PGE}_{2}$ is not unexpected as IL-1 is known to stimulate gene expression for cyclooxygenase (16) as well as phospholipase $A_{2}(45)$. Thus, the marked increased in $\mathrm{PGE}_{2}$ observed at $48 \mathrm{~h}$ may be a modulating factor responsible, in part, for the decrease in inflammation observed at $96 \mathrm{~h}$. Prostaglandins may act through inhibition of cytokine production $(4,46,47)$, inhibition of leukotriene synthesis (48) or immune suppression (49).

Secondary inflammatory cytokines may be involved in the pathogenesis of inflammation in this model. These would include the ability of IL-1 to initiate transcription of IL-8 $(50,51)$ and GM-CSF (52). The IL-8 gene is rapidly expressed upon exposure to IL-1 and IL-8 is chemotactic for neutrophils and
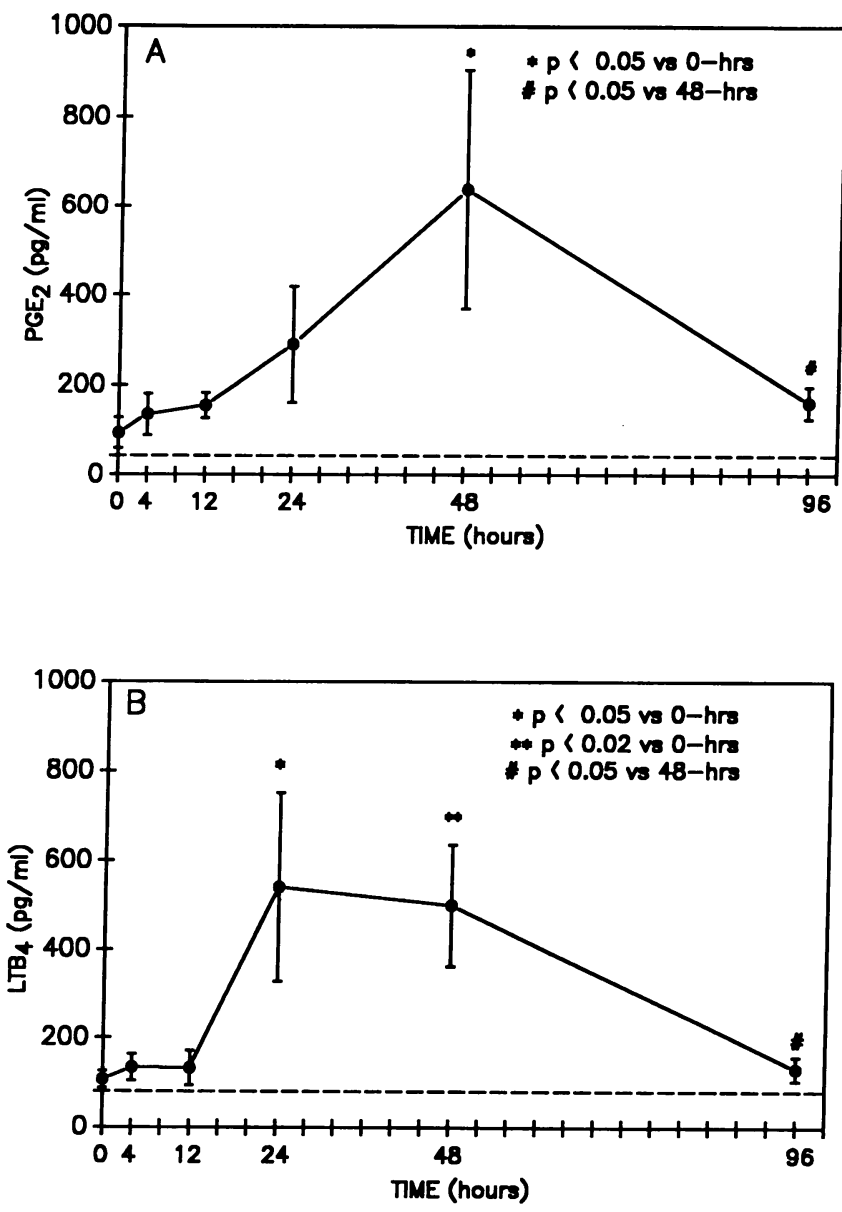

Figure 4. Time course of colonic $\mathrm{PGE}_{2}$ and $\mathrm{LTB}_{4}$ production after administration of immune complexes. $\mathrm{PGE}_{2}$ and $\mathrm{LTB}_{4}$ were measured in rectal dialysates at the time points indicated. $\mathrm{PGE}_{2}$ production was significantly increased only $48 \mathrm{~h}$ after the induction of colitis $(P<0.05)$. $\mathrm{LTB}_{4}$ levels were significantly increased at $24(P$ $<0.05)$ and $48 \mathrm{~h}(P<0.02)$. At $96 \mathrm{~h}$, colonic $\mathrm{PGE}_{2}$ and $\mathrm{LTB}_{4}$ production diminished to levels similar to those observed in control rabbits $(P<0.05)$. Each point represents the mean \pm SEM of five rabbits. (A) $\mathrm{PGE}_{2}$. (B) $\mathrm{LTB}_{4}$. 

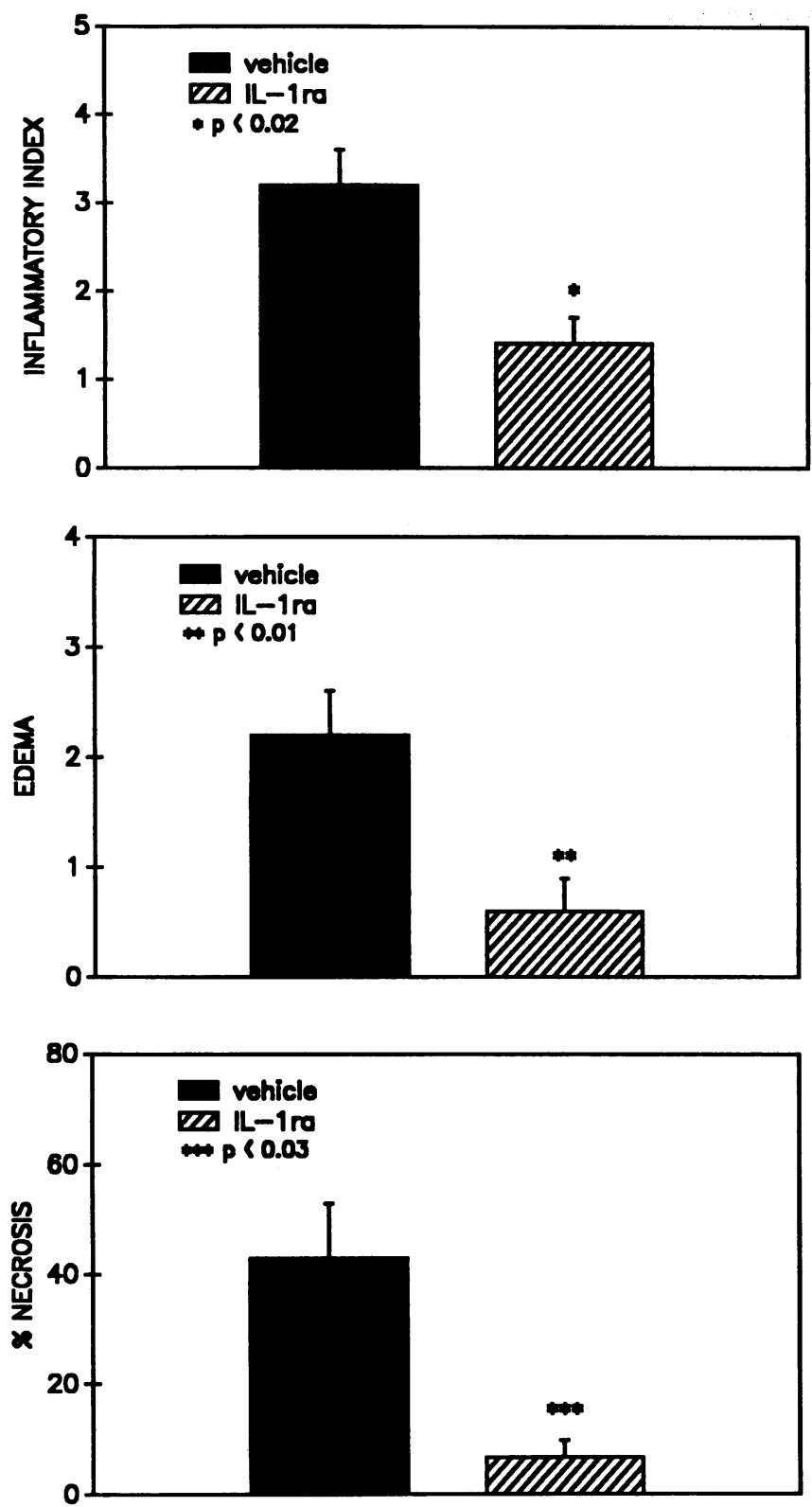

Figure 5. Effects of treatment with IL-1 ra on inflammation and tissue damage in rabbit immune colitis. IL- $1 \mathrm{ra}(5 \mathrm{mg} / \mathrm{kg} ; n=8)$ was administered intravenously $2 \mathrm{~h}$ before and $1,9,17,25,33 \mathrm{~h}$ after the immunocomplex administration. Control rabbits $(n=10)$ were treated with vehicle $(0.5 \mathrm{ml}$ PBS). Each bar represents the mean \pm SEM. Asterisks indicate significant differences between the two groups $\left({ }^{*} P<0.02,{ }^{* *} P<0.01,{ }^{* * *} P<0.03\right)$. Statistical analysis was performed using the Mann-Whitney two-sample test.

lymphocytes (53). Related molecules in this family also include macrophage inflammatory proteins some of which are structurally related to IL-8, while others produce different inflammatory effects such as edema and capillary leakage. GMCSF increases neutrophil superoxide production, which may be involved in tissue damage $(54,55)$. IL- 1 is also an inducer of TNF (56) and IL-6 (57). Although IL-6 has no intrinsic inflammatory properties, its ability to stimulate B cells as well as $\mathbf{T}$ cells may contribute to the prolongation of tissue response to certain antigens. Finally, the synergism between IL-1 and TNF in inducing capillary-leak syndromes (58), $\mathrm{PGE}_{2}$ synthesis (59) and cell death (60) are well established. Thus, the early expression of IL-1 in this model suggests a mechanism whereby IL-1 initiates a cascade of other cytokines acting independently or synergistically with IL-1.

A role for lipid mediators such as $\mathrm{LTB}_{4}$ and platelet activating factor (PAF) in the induction and enhancement of colon inflammation in experimental colitis has been proposed by several studies $(18,61-63)$. In this study, LTB $_{4}$ synthesis was documented only $24 \mathrm{~h}$ after the induction of colitis and did not correlate with the development of inflammation or necrosis. This suggests that $\mathrm{LTB}_{\mathbf{4}}$ production may be a secondary event, possibly a consequence of neutrophil infiltration. One possible sequence of events would be initial synthesis of IL-1 followed by expression of IL-8, IL-8 chemotaxis of neutrophils with subsequent production of $\mathrm{LTB}_{4}(64)$. These data are consistent with our preliminary studies (unpublished observations) in which administration of specific $\mathrm{LTB}_{4}$ receptor blockers or PAF antagonists to rabbits with formalin-immune complex colitis failed to reduce inflammation or tissue damage. However, $\mathrm{LTB}_{4}$ is a potent chemotactic agent for neutrophils and monocytes and could be involved in amplifying the initial inflammatory stimulus.

Although some of the naturally occurring inhibitors of IL-1 activity are non-specific (for example, lipoproteins and uromodulin), the existence of a specific IL-1 inhibitor was demonstrated by its ability to block IL-1 but not mitogen or IL-2 induced thymocyte proliferation. The initial observation of a specific IL-1 inhibitor was made in the sera from human volunteers receiving endotoxin (65) and this was followed by reports of specific IL-1 inhibitory activity in the urine of febrile patients (66) and patients with monocyte leukemia (67). The urinary inhibitor was partially purified as a $23-\mathrm{kD}$ protein (68) and the mechanism of its action was shown to be at the level of blocking the binding of IL-1 to T cells and fibroblasts (68) and reduction in biological responses to IL-1 (69). The production of IL-1 inhibitory activity was also shown by human monocytes stimulated with immune complexes (70) and was shown to be specific. This latter report has particular significance for the model of colitis we use. The purification, cloning, and expression of recombinant IL-1 inhibitor (23) have provided material to show that it is a pure receptor antagonist with no agonist activity and termed the IL-1ra. This protein has allowed us to examine the effects of a specific blockade of IL-1 receptors in the colitis model.

There are two distinct IL-1 receptors in murine cells; an 80-kD glycoprotein found on T cells, fibroblasts, hepatocytes, and natural killer cells and a $68-\mathrm{kD}$ protein found on B cells, macrophages, and neutrophils (71-73). Initial studies have shown that the recombinant nonglycosylated IL-1 ra $(a)$ binds to cells expressing primarily the $80-\mathrm{kD}$ IL-1 receptor with nearly the same affinity as IL-1; and (b) competes with either IL- $1 \alpha$ or IL- $1 \beta$ on these cells (24). The IL- 1 ra does not bind to murine cell lines expressing the $68-\mathrm{kD}$ receptor. This may suggest that the receptors in rabbit colonic tissue are of the $80-\mathrm{kD}$ type. However, since the IL-1 ra shares 26 identical and $40 \%$ amino acid homology with IL- $1 \beta$ and 19 identical and $26 \%$ conserved homology with IL- $1 \alpha$, the IL-1 ra may also block the binding of IL-1 to the $68-\mathrm{kD}$ rabbit IL-1 receptor. Although the nature of the cell targets for the IL-1 in the colitis model remains unknown, the present studies establish the effi- 

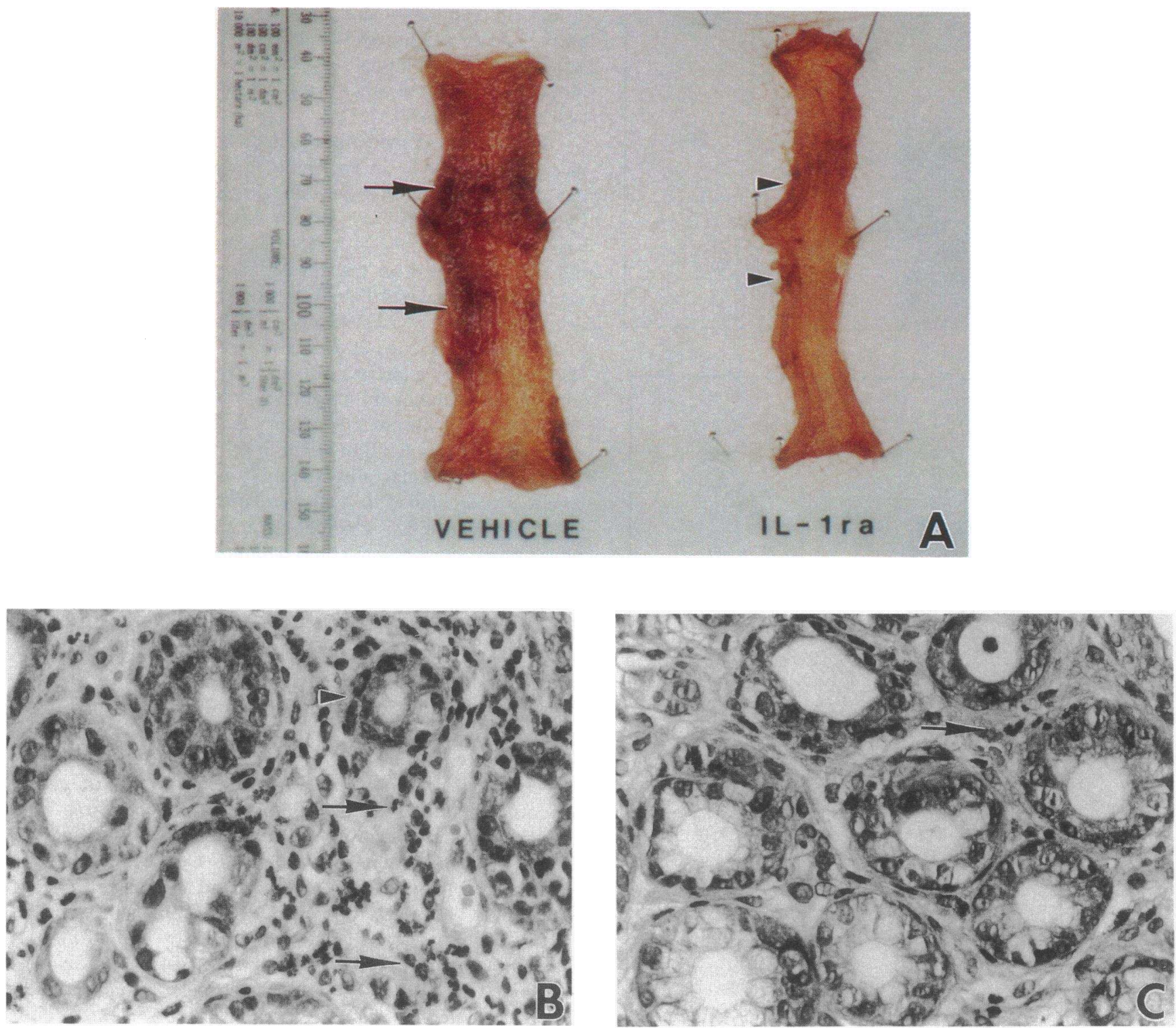

Figure 6. Representative colonic gross and microscopic appearance after IL-1 ra or vehicle treatment. $(A)$ The vehicle-treated colon is thicken with large areas of erythema and focal necrosis (arrows). The IL-1 ra-treated colon has only few foci of erythema (arrowheads). (B) Vehicletreated colon showing many neutrophils in the lamina propria (arrows) and epithelial cell mucus depletion (arrowhead). Hematoxylin and eosin $\times 300$. $(C)$ Colon treated with IL-1 ra demonstrating few inflammatory cells (arrow) and intact epithelium. Hematoxylin and eosin $\times 300$.

cacy of the IL-1 ra to block the in vivo activity of IL-1 produced in the colon. Other pro-inflammatory cytokines induced by the immune complexes in colitis are either playing a secondary role or are expressed subsequent to IL-1 synthesis.

\section{Acknowledgments}

The authors thank Marjorie Lee and Jennie Jing for technical assistance. We acknowledge Dr. Alan R. Shaw and Dr. Paul Wingfield of the Glaxo Institute of Molecular Biology, Geneva, Switzerland and Joseph G. Cannon of Tufts University for their valuable contribution to this work regarding the cloning and expression of rabbit interleukin-1. We also thank Robert D. Zipser for helpful discussion of the manuscript.

This work was support in part by grants DK-36869 and AI-15614 from the National Institutes of Health. Dr. Cominelli is a recipient of a
Career Development Award from the Blinder Foundation for Crohn's disease.

\section{References}

1. Dinarello, C. A. 1989. Interleukin-1 and its biologically related cytokines. Adv. Immunol. 44:153-205.

2. Auron, P. E., A. C. Webb, L. J. Rosenwasser, S. F. Mucci, A. Rich, S. M. Wolff, and C. A. Dinarello. 1984. Nucleotide sequence of human monocyte interleukin-1 precursor cDNA. Proc. Natl. Acad. Sci. USA. 81:7907-7911.

3. Lomedico, P. T., U. Gubler, C. P. Hellman, M. Dukovich, J. G. Giri, Y. E. Pan, K. Collier, R. Seminonow, A. O. Chua, and S. B. Mizel. 1984. Cloning and expression of murine interleukin-1 in Escherichia coli. Nature (Lond.). 312:458-462.

4. Endres, S., J. C. Cannon, R. Ghorbani, R. A. Dempsey, S. D. 
Sisson, G. Lonneman, J. W. M. van der Meer, S. M. Wolff, and C. A. Dinarello. 1989. In vitro production of IL- $1 \beta$, IL- $1 \alpha$, TNF and IL-2 in healthy subjects: distribution, effect of cyclooxygenase inhibition and evidence of independent gene regulation. Eur. J. Immunol. 19:23272333.

5. Neta, R., and J. J. Oppenheim. 1988. Why should internist be interested in interleukin-1? Ann. Intern. Med. 109:1-3.

6. O'Garra, A. 1989. Interleukins and the immune system. Lancet. i:943-947.

7. Fontana, A., H. Hengarrtner, E. Weber, K. Fehr, P. J. Grob, G. Cohen. 1982. Interleukin-1 activity in the synovial fluid of patients with rheumatoid arthritis. Rheumatol. Int. 2:49-53.

8. Wood, D. D., E. J. Ihrie, C. A. Dinarello, P. L. Cohen. Isolation of an interlukin-1-like factor from human joint effusions. 1983. Arthritis Rheum. 26:975-981.

9. Eastgate, J. A., J. A. Symons, N. C. Wood, F. M. Grinlinton, F. S. di Giovine, and G. W. Duff. 1988. Correlation of plasma interleukin-1 levels with disease activity in reumatoid arthritis. Lancet. ii:706-709.

10. Girardin, E., G. E. Grau, J. M. Dayer, P. Roux-Lombard, and P. H. Lambert. 1988. Tumor necrosis factor and interleukin-1 in the serum of children with severe infectious purpura. N. Engl. J. Med. 319:385-392.

11. Cannon, J. G., R. G. Tompkins, J. A. Gelfand, H. R. Michie, G. G. Stanford, J. W. M. van der Meer, S. Endres, G. Lonnemann, J. Corsetti, B. Chernow, D. W. Wilmore, S. M. Wolff, J. F. Burke, and C. A. Dinarello. 1990. Circulating interleukin- $1 \beta$ and tumor necrosis factor in septic shock and experimental endotoxin fever. J. Infect. Dis. 161:79-84.

12. Martini, A., A. Ravello, L. D. Notarangelo, R. Maccario, A. Lanfranchi, D. Rondena, A. G. Ugazio, and R. Burgio. 1986. Enhanced interleukin-1 and depressed interleukin-2 production in juvenile arthritis. J. Rheumatol. 13:3-16.

13. Shore, A., S. Jagial, and E. C. Keystone. 1986. Enhanced interleukin-1 generation by monocyte in vitro is temporally linked to an early event in the onset or exacerbation of rheumatoid arthritis. Clin. Exp. Immunol. 65:293-302.

14. Satsangi, J., R. A. Wolstencroft, J. Cason, C. C. Ainley, A. C. Dumonde, and R. P. H. Thompson. 1987. Interleukin 1 in Crohn's disease. Clin. Exp. Immunol. 67:594-605.

15. Movat, H. Z., M. I. Cybulsky, I. G. Colditz, M. K. Chan, and C. A. Dinarello. 1987. Acute inflammation in gram-negative infection endotoxin, interleukin 1, tumor necrosis factor, and neutrophils. Fed. Proc. 46:97-104.

16. Raz, A., A. Wyche, N. Siegel, and P. Needleman. 1988. Regulation of fibroblast cyclooxygenase synthesis by interleukin-1. J. Biol. Chem. 263:3022-3028.29.

17. Cominelli, F., C. C. Nast, C. A. Dinarello, P. Gentilini, and R. D. Zipser. 1989. Regulation of eicosanoid production in rabbit colon by interleukin-1. Gastroenterology. 97:1400-1405.

18. Zipser, R. D., C. C. Nast, M. Lee, H. W. Kao, and R. Duke. 1987. In vivo production of leukotriene $B_{4}$ and $C_{4}$ in rabbit colitis. Gastroenterology. 92:33-39.

19. Brown, J. A., and R. D. Zipser. 1987. Prostaglandin regulation of colonic blood flow in rabbit colitis. Gastroenterology. 92:54-59.

20. Schumert, R., C. C. Nast, F. Cominelli, and R. D. Zipser. 1988. Effects of 16,16-dimethyl prostaglandin $E_{2}$ and indomethacin on leukotriene $\mathbf{B}_{4}$ and inflammation in rabbit colitis. Prostaglandins. 36:565-577.

21. Cannon, J. G., B. D. Clark, P. Wingfield, U. Schmeissner, C. Losberger, C. A. Dinarello, and A. Shaw. 1989. Rabbit IL-1. Cloning, expression, biologic properties, and transcription during endotoxemia. J. Immunol. 142:2299-2306.

22. Clark, B. D., I. Bedrosian, R. Schindler, F. Cominelli, J. G. Cannon, A. R. Shaw, and C. A. Dinarello. 1990. Levels of interleukin$1 \alpha$ and $\beta$ in various tissues during endotoxemia in rabbits using sensitive radioimmunoassays. $J$. Appl. Physiol. In press.
23. Eisenberg, S. P., R. J. Evans, W. P. Arend, E. Verderber, M. T. Brewer, C. H. Hannum, and R. C. Thompson. 1990. Primary structure and functional expression from complementary DNA of a human interleukin-1 receptor antagonist. Nature (Lond.). 343:341-346.

24. Hannum, C. H., C. J. Wilcox, W. P. Arend, G. F. Joslin, D. J. Dripps, P. L. Heimdal, G. L. Armes, A. Sommer, S. P. Eisemberg, and R. C. Thompson. 1990. Interleukin-1 receptor antagonist activity of a human interleukin-1 inhibitor. Nature (Lond.). 343:336-340.

25. Kirsner, J. B., and J. Elchlepp. The production of an experimental ulcerative colitis in rabbits. 1957. Trans. Assoc. Am. Phys. 70:102-119.

26. Hodgson, H. J. F., B. J. Potter, J. Skinner, and D. P. Jewell. 1978. Immune-complex mediated colitis in rabbits. An experimental model. Gut. 19:225-232.

27. Arend, W. P., H. G. Welgus, R. C. Thompson, and S. P. Eisenberg. 1990. Biological properties of recombinant human monocyte-derived IL-1 receptor antagonist. J. Clin. Invest. 85:1694-1697.

28. Eisemberg, S. P., R. C. Thompson, and N. G. Cox. 1989. An interleukin-1 inhibitor (IL-1i) blocks IL-1 induced adhesion of neutrophils to endothelial cells. Cytokine. 1:106a. (Abstr.)

29. Dayer, J. M., and P. Seckinger. 1989. Natural inhibitors and antagonists of interleukin-1. In Interleukin-1, inflammation and disease. R. Bomford and B. Henderson, editors. Elsevier/North Holland Biomedical Publishers, New York. 284-302.

30. Ohlsson, K., P. Bjork, M. Bergenfeldt, S. P. Eisenberg, J. Childs, C. H. Hannum, and R. C. Thompson. 1989. Human IL-1 inhibitor (IL-li) blocks the effects of IL-1 $\beta$ in the rabbit. Cytokine. 1:131a. (Abstr.)

31. Maniatis, T., E. F. Fritsch, J. Sambrook, editors. 1987. Molecular cloning. 3rd ed. Cold Spring Harbor, NY. 188-209, 387-389.

32. Ausubel, F. M., R. Brent, R. E. Kingston, D. D. Moore, J. A. Smith, J. G. Seidman, and K. Struhl. 1987. Current Protocols in Molecular Biology. Green Publishing Assoc., John Wiley \& Sons, New York. 4.9.1-4.9.7.

33. Zipser, R. D., J. B. Patterson, H. W. Kao, C. J. Hauser, and R. Locke. 1985. Hypersensitive prostaglandin and thromboxane response to hormones in rabbit colitis. Am. J. Physiol. 249:G457-463.

34. Zipser, R. D., J. B. Patterson, and L. E. LeDuc. 1987. Differential regulation of prostaglandin, thromboxane and leukotriene biosynthesis in rabbit colitis. J. Pharmacol. Exp. Ther. 241:218-222.

35. Rachmilewitz, D., P. L. Simon, L. W. Schartz, D. E. Griswold, J. D. Fondacaro, and M. Wasserman. 1989. Inflammatory mediators of experimental colitis in rats. Gastroenterology. 97:326-337.

36. Yoshimura, T., K. Matsushima, J. J. Oppenheim, and E. J. Leonard. 1987. Neutrophils chemotactic factor produced by lipopolysaccharide (LPS)-stimulated human blood mononuclear leukocytes: partial characterization and separation from interleukin-1 (IL-1). $J$. Immunol. 139:788-793.

37. Peveri, P., A. Waltz, B. Dewald, and M. Baggiolini. 1988. A novel neutrophil-activating factor produced by human mononuclear phagocytes. J. Exp. Med. 167:1547-1559.

38. Strieter, R. M., S. L. Kunkel, H. J. Showell, G. D. Remick, S. H. Phan, P. A. Ward, and R. M. Marks. 1989. Endothelial cell gene expression of a neutrophil chemotactic factor by TNF, IL-1 and LPS. Science (Wash. DC). 243:1467-1469.

39. Matsushima, K., K. Morishita, T. Yoshimura, S. Lavu, Y. Kobayashi, W. Lew, E. Appella, H. F. Kung, E. J. Leonard, and J. J. Oppenheim. 1988. Molecular cloning of a human monocyte-derived neutrophil chemotactic factor (MDNCF) and the induction of MDNFC mRNA by interleukin-1 and tumor necrosis factor. $J$. Exp. Med. 167:1883-1893.

40. Demczuk, S., C. Baumberger; B. Mach, and J. M. Dayer. 1987. Expression of human IL- $1 \alpha$ and $\beta$ messenger RNAs and IL-1 activity in human peripheral blood mononuclear cells. J. Mol. Cell. Immunol. 3:255-265.

41. Lonneman, G., S. Endres, J. W. M. van der Meer, J. G. Cannon, K. M. Koch, and C. A. Dinarello. 1989. Differences in the synthe- 
sis and kinetics of release of interleukin- $1 \alpha$, interleukin- $1 \beta$ and tumor necrosis factor from human mononuclear cells. Eur. J. Immunol. 19:1531-1536.

42. Endres, S., R. Ghorbani, G. Lonneman, J. W. M. van der Meer, S. M. Wolff, and C. A. Dinarello. 1988. Measurement of immunoreactive interleukin- $1 \beta$ from human mononuclear cells: optimization of recovery, intrasubject consistency, and comparison with interleukin$1 \alpha$ and tumor necrosis factor. Clin. Immunol. Immunopathol. 49:424-438.

43. Kupper, T. S., D. W. Ballard, A. O. Chua, J. S. McGuire, P. M. Flood, M. C. Horowitz, R. Langdon, L. Lightfoot, and U. Gubler. 1986. Human keratinocytes contain mRNA indistinguishable from monocyte interleukin- $1 \alpha$ and $\beta$ mRNA. J. Exp. Med. 164:2095-2100.

44. Cominelli, F., C. C. Nast, J. Tower, R. D. Zipser, and C. A. Dinarello. 1990. Interleukin-1 suppresses inflammation in rabbit colitis: Mediation by endogenous prostaglandins. J. Clin. Invest. 85:582-586.

45. Chang, J., S. C. Gilman, and A. J. Lewis. 1986. Interleukin-1 activates phospholipase $A_{2}$ in rabbit chondrocytes: a possible signal for interleukin-1 action. J. Immunol. 136:1283-1287.

46. Knudsen, P. J., C. A. Dinarello, and T. B. Strom. 1986. Prostaglandins post-transcripyionally inhibit monocyte expression of interleukin 1 activity by increasing intracellular cyclic adenosine monophosphate. J. Immunol. 137:3189-3194.

47. Dinarello, C. A., R. A. Dempsey, M. Allegretta, G. LoPreste, N. Dainak, D. R. Parkinson, and J. W. Mier. 1986. Inhibitory effects of elevated temperature on human cytokine production and natural killer activity. Cancer Res. 46:6236-6241.

48. Ham, E. A., D. D. Soderman, M. E. Zaneti, H. W. Dougherty, E. McCauley, and F. Kuehl. 1983. Inhibition by prostaglandins of leukotriene $\mathrm{B}_{4}$ release from activated neutrophilis. Proc. Natl. Acad. Sci. USA. 80:4349-4353.

49. Goodwin, J. G., and J. Ceuppen. 1983. Regulation of the immune response by prostaglandins. J. Clin. Immunol. 3:295-315.

50. Strieter, R. M., S. H. Phan, H. J. Showell, D. G. Remick, J. P. Linch, M. Gerard, C. Reiford, M. Eskandari, R. M. Marks, and S. L. Kunkel. 1989. Monokine-induced neutrophils chemotactic factor gene expression in human fibroblasts. J. Biol. Chem. 264:10621-10626

51. Larsen, C. G., L. O. Zachariae, J. J. Oppenheim, and K. Matsushima. 1989. Production of monocyte chemotactic factor and activating factor (MCFAF) by human dermal fibroblasts in response to interleukin-1 or tumor necrosis factor. Biochem. Biophys. Res. Commun. 160:1403-1408.

52. Zucali, J. R., C. A. Dinarello, D. J. Oblon, M. A. Gross, L. Anderson, and R. S. Wiener. 1986. Interleukin-1 stimulates fibroblasts to produce granulocyte-macrophage colony-stimulating activity and prostaglandin $\mathrm{E}_{2}$. J. Clin. Invest. 77:1857-1863.

53. Baggiolini, M., A. Walz, and S. L. Kunkel. 1989. Neutrophilactivating peptide-1/interleukin-8, a novel cytokine that activates neutrophils. J. Clin. Invest. 84:1045-1049.

54. Weisbart, R. H., D. W. Golde, S. C. Clark, G. G. Wong, and J. C. Gasson. 1985. Human granulocyte-macrophage colony-stimulating factor is a neutrophil activator. Nature (Lond.). 314:361-366.

55. Lopez, A. F., J. Williamson, J. R. Gamble, C. G. Begley, J. M. Harlan, S. J. Klebanoff, A. Waltersdorph, G. Wong, S. C. Clark, and M. A. Vadas. 1986. Recombinant human granulocyte-macrophage colony-stimulating factor stimulates in vitro mature human neutrophil and eosinophil function, surface receptor expression, and survival. $J$. Clin. Invest. 78:1220-1228.

56. Ikejima, T., S. Okusawa, P. Ghezzi, J. W. M. van der Meer, and C. A. Dinarello. 1990. IL-1 induces TNF in human PBMC in vitro and a circulating TNF-like activity in rabbits. J. Infect. Dis. 162:215-223.

57. Van Damme, J., and A. Billiau. 1987. Identification of human
$26-\mathrm{kD}$ protein, interferon $\beta-2$, as a $\mathrm{B}$ cell hybridoma/plasmacytoma growth factor induced by interleukin-1 and tumor necrosis factor. $J$. Exp. Med. 165:914-919.

58. Okusawa, S., J. A. Gelfand, T. Ikejima, R. J. Connolly, and C. A. Dinarello. 1988. Interleukin-1 induces a shock-like state in rabbits. Synergism with tumor necrosis factor and the effect of cyclooygenase inhibition. J. Clin. Invest. 81:1162-1172.

59. Elias, J. A., K. Gustilo, W. Baeder, and B. Freundlich. 1987. Synergistic stimulation of fibroblast prostaglandin production by recombinant interleukin-1 and tumor necrosis factor. J. Immunol. 138:3812-3816.

60. Vogel, S. N., E. N. Kaufman, M. D. Tate, and R. Neta. 1988. Recombinant interleukin-1a and recombinant tumor necrosis factora synergize in vivo to induce early endotoxin tolerance and associated hematopoietic changes. Infect. Immun. 56:2650-2657.

61. Sharon, P., and W. F. Stenson. 1985. Metabolism of arachidonic acid metabolism in acetic acid colitis. Gastroenterology. 88:5563.

62. Wallace, J. L., W. K. MacNaughton, G. P. Morris, and P. L. Beck. 1989. Inhibition of leukotriene synthesis markedly accelerates healing in a rat model of inflammatory bowel disease. Gastroenterology. 96:29-36.

63. Eliakim, R., F. Karmeli, E. Razin, and D. Rachmilewitz. 1988 Role of platelet-activating factor in ulcerative colitis. Enhanced production during active disease and inhibition by sulfasalazine and prednisone. Gastroenterology. 95:1167-1172.

64. Schroder, J. M. 1989. The monocyte-derived neutrophil activating peptide (NAP/interleukin-8) stimulates human neutrophil arachidonate-5-lipoxygenase, but not the release of cellular arachidonate. J. Exp. Med. 170:847-863.

65. Dinarello, C. A., L. J. Rosenwasser, and S. M. Wolff. 1981. Demonstration of a circulating suppressor factor of thymocyte proliferation during endotoxin fever in humans. J. Immunol. 127:25172519.

66. Liao, Z., R. S. Grimshaw, and D. L. Rosenstreich. 1984. Identification of a specific interleukin-1 inhibitor in the urine of febrile patients. J. Exp. Med. 159:126-136.

67. Seckinger, P., and J. M. Dayer. 1987. Interleukin-1 inhibitors. Ann. Inst. Pasteur/Immunol. 138:461-516.

68. Seckinger, P., J. W. Lowenthal, K. Williamson, J. M. Dayer, and H. R. MacDonald. 1987. A urine inhibitor of interleukin-1 activity that blocks ligand binding. J. Immunol. 139:1546-1549.

69. Balavoine, J. F., B. de Rochemonteix, K. Williamson, P. Seckinger, A. Cruchaud, and J. M. Dayer. 1986. Prostaglandin $E_{2}$ and collagenase production by fibroblast and synovial cells is regulated by urine-derived human interleukin 1 and inhibitor(s). J. Clin. Invest. 78:1120-1124.

70. Arend, W. P., F. G. Joslin, R. C. Thompson, and C. H. Hannum. 1989. An IL-1 inhibitor from human monocytes. Production and characterization of biologic properties. J. Immunol. 143:18511858.

71. Horuk, R., J. J. Huang, M. Covington, and R. C. Newton. 1987. A biochemical and kinetic analysis of the interleukin-1 receptor. Evidence for differences in molecular properties of IL-1 receptors. $J$. Biol. Chem. 262:16275-16278.

72. Chizzonite, R., T. Truitt, P. L. Kilian, A. S. Stern, P. Nunes, K. P. Parker, K. L. Kaffka, A. O. Chua, D. K. Lugg, and U. Gluber. 1989. Two high-affinity interleukin-1 receptors represent separate gene products. Proc. Natl. Acad. Sci. USA. 86:8029-8033.

73. Bomsztyk, K., J. E. Sims, T. H. Stanton, J. Slack, C. J. McMahan, M. A. Valentine, and S. K. Dower. 1989. Evidence for different interleukin-1 receptors in murine B-and T-cell lines. Proc. Natl. Acad. Sci. USA. 86:8034-8038. 